\title{
Governance Structure of Microfinance Institutions: A Comparison of Models and Its Implication on Social Impact and Poverty Reduction*
}

\section{Mikro Finans Kurumlarının Yönetişim Yapısı: Bir Model Karşılaştırması ve Sosyal Etki ve Yoksullukla Mücadele üzerine Çıkarımlar}

\author{
(D) Md Nazim Uddin(1), (D) Hamdino Hamdan(2), \\ Nor Azizan Che Embi(3), (1D Salina Kassim(4), (D) Norma Bt Md Saad(5) \\ $(1,2,3,4,5)$ International Islamic University Malaysia \\ (1)nazim.uddin@live.iium.edu.my, (2)hamdino@iium.edu.my, (3)izanebbm@iium.edu.my, \\ (4)ksalina@iium.edu.my, (5)norma@iium.edu.my
}

Received: June 1, 2019

Accepted: October 1, 2019

Published: January 15,2020

\begin{abstract}
The purpose of this paper is to compare three different models of MFIs, namely microfinance banks (MFB), Microcredit programme (MCP) and rural development scheme (RDS), by focusing on their governance structures, and subsequently analyse their implications on social impact and poverty reduction of the MFIs. Three MFIs, one from each model, will be considered, using Bangladesh as the case study. Bangladesh is a country which is considered to be a pioneer in providing micro-finance to the underprivileged people to improve their entrepreneurial capacity. In methodology, the study relies on Porter's Competitive Strategy Theory (1979). This theory is based on the concept that five forces determine the competitive intensity and attractiveness of a market which assesses five forces. The study relies on secondary data collected mainly from the annual reports of the three MFIs, and Microcredit Regulatory Authority (MRA) report. This study aims to contribute towards better governance practices of the MFIs given its strong implications on social responsibility, accountability, transparency, financial performance, increasing their social impact and poverty reduction of the MFIs. Findings of this study provide essential inputs on the way forward for the evolution of microfinance, as framed by the global development discourse and subsequent public policy choices. Overall, the study shows that only a limited number of variables influence the social impact and poverty reduction of an MFI. The limitation of the studied investment fund is that it invests in expanding and mature MFI's. So the
\end{abstract}

ORC-ID: M.N. Uddin 0000-0001-8934-6136; H. Hamdan 0000-0002-5560-3162; N.A Che Embi 0000-0003-17116440; S. Kassim 0000-0002-7514-8750; N.B.M. Saad 0000-0002-2455-904X

${ }^{*}$ This article is a review of the paper presented at the "5th International Ibn Khaldun Symposium" organized on $27-$ 28 April 2019 in Istanbul. 
results of this research can only be generalised to expanding and mature MFl's. The approach to microfinance governance should be broadened by focusing more on stakeholders and the decision making process in an MFI. Better social responsibility and poverty reduction of the MFIs contribute positively to financial inclusion through poverty alleviation, empowerment of the poor and better financial access, leading to sustainable economic growth.

Keywords: Governance Structure, Microfinance, Social Impact, Microfinance Banks, Rural Development Scheme

Öz: Bu makalenin amacı Mikro Finans Bankaları, Mikro Kredi Programları ve kırsal kalkınma planları gibi farklı Mikro Finans Kurumları (MFK) modellerini yönetişim yapılarına odaklanarak karşılaştırmak ve akabinde bunlara ilişkin sosyal etki ve yoksulluğun azaltılması konusunda yapılacak çıkarımların analiz edilmesidir. Her biri farklı bir model olmak üzere üç farklı MFK, Bangladeş örneği üzerinden ele alınacaktır. Bangladeş sosyal haklardan mahrum insanların girişimcilik kapasitesini arttırmak için onlara mikro kredi sağlama konusunda öncü rol oynayan bir ülke olarak değerlendirilmektedir. Bu çalışma metodolojik olarak Porter'ın Rekapetçi Strateji Teorisine (1979) dayanmaktadır. Bu teori bir piyasanın çekiciliğini ve rekabetin yoğunluğunu belirleyen beş temel etken yaklaşımını esas almakta; temelde MFK'ların yıllık raporlarından ve Mikro Kredi Düzenleme Ajansı (MKDA) raporundan derlenen ikincil veriye dayanmaktadır. Bu çalışma sosyal etkiyi arttıran ve fakirliği azaltan MFK'ların sosyal sorumluluk, hesap verebilirlik, şeffaflık, finansal performans üzerindeki güçlü etkisi göz önüne alındığında, bu kurumlardaki iyi yönetişim uygulamalarına katkı sağlamayı amaçlamaktadır. Çalışmanın bulguları kamu politikaları tercihleri ve küresel kalkınma söylemlerinde yerini almış olan mikro finans yapılarının değerlendirilmesine dönük ciddi katkılar sağlamaktadır. Genel anlamıyla çalışma kısıtı sayıda değişkenin sosyal etkiyi arttırıcı ve yoksulluğu azaltıcı etkisinin olduğunu göstermektedir. Çalışmanın kısıtı olarak makaleye konu olan yatırım fonunun sadece gelişmekte olan ve gelişmiş MFK'larına yatırım yapmasını zikredebiliriz. Bu nedenle çalışmanın sonuçları sadece bu tür MFK'ları için genellenebilir. Mikro finans yönetişim konusu diğer paydaşlara ve bir MFK'daki karar verme sürecine uygulanabilir. MFK'ların daha iyi bir sosyal sorumluluk ve yoksulluk ile mücadele seviyesine ulaşması, yoksulların güçlendirilmesi ve finansal kaynaklara ulaşımlarının iyileştirilmesi yoluyla finansal katıımcılığın olumlu yönde gelişmesine katkı sağlayacaktır.

Anahtar Kelimeler: Yönetişim Yapısı, Mikro Finans, Sosyal Etki, Mikro Finans Bankaları, Kırsal Kalkınma Planı

\section{Introduction}

Bangladesh presents a unique opportunity for studying specific detail aspects of microfinance given a numerous and diversified model of microfinance existed in the country. Ever since the start of microfinance in Bangladesh in 1978 through Grameen Bank, the microfinance industry in the country has continued to expand and evolve rapidly. Bangladesh has a most significant and most wide-ranging microfinance 
program in the world, with more than 34.76 million active borrowers and BDT 1313.67 (USD' 16.42) billion gross loan portfolio. This sector manages BDT 771.80 (USD 9.65) billion worth of deposits from 39.48 million depositors who are often referred to as members. The general network of six hundred fifty-five MFls has provided to access to financial service to $77 \%$ of the population. Moreover, according to the microfinance regulatory board (MRA, 2017), conclusions are drawn from an analysis of the microfinance social impact, poverty reduction and governance issues in Bangladesh can be generalised for an entire industry.

One of the areas that are currently capturing the attention of the stakeholders is the impact of commercialisation on the depth of social impact, as now there are three distinct models of microfinance operating side-by-side in the country: the microfinance bank (MFB), microcredit program (MCP) and rural development scheme (RDS). MCPs are mostly NGOs, while MFBs are Banking institutions and RDS is Islamic microfinance system, wherein the context of Bangladesh, are regulated by the central bank of Bangladesh, Credit and Development Forum (CDF) and Microcredit Regulatory Authority (MRA). In essence, social impact and poverty reduction are the primary goals for MFIs. However, it is activities to provide credit to the poor (Hermes, Lensink, \& Meesters, 2011) Many MFIs in the developing countries have had limited achievements in cost efficiency, thus there is an excellent challenge for the MFIs to choose between social impact and poverty reduction (Baklouti, 2013 \& Parvin et al., 2018). Social impact and poverty reduction are considered as the benchmark of MFIs performance (Baklouti, 2013). Yunus (2007) highlighted that a financially sustainable institution could ensure long-term operation and service to society.

Similarly, in the context of MFIs, sustainable, efficient MFI can serve the social purpose better than a bankrupt MFI, and several studies were conducted to investigate the impact of microcredit programs in different regions. However, there has been a little study conducted on the MFIs' financial sustainability. Additionally, several studies recently showed MFIs declining financial performances, and this has brought the need of examining the efficiency of MFIs (Wagner \& Winkler, 2013; Azad, Masum, Munisamy, \& Sharmin, 2016).

The Grameen Bank is the first model to introduce the idea of microcredit. This model has been replicated by many other microfinance institutions (MFIs) such as the Self Help Group (SHP). MFBs has also introduced some unique features in providing financial

1 USD 1 = BDT 80. 
services to the poor. Both types of model are popular and widely used in the country and even outside of Bangladesh. Another popular model is RDS of IBBL which provides some services to the poor according to the shariah principle.

This study analyses three models of MFIs in their governance structures and operational aspects, and these have important implications particularly regarding how the MFIs deal with their borrowers. The principles of conventional MFIs are different from Islamic MFIs in many issues. The practice of interest is the most distinctive feature in conventional MFIs, whereas the principle of profit loss sharing is the key feature of Islamic MFIs.

This study will first present a thorough comparative analysis of MFIs, MFBs versus RDS. Second, by analysing how organisational governance structure impacts institutional practices, including client poverty reductions and social impact the institutional parameters of transparency, reliability, and flexibility - especially relevant for microfinance (Parvin, Mohiuddin, Hoque, \& Su, 2018).

On the backdrop of these issues, this study aims to conduct a comprehensive analysis of the three main models of microfinance, namely the MBF, MCP, and RDS, and subsequently compare the operational structure and the services offered by the MFIs as well as their functions. In particular, a comparison will be made in the financial performance of Grameen, MFI, and RDS, covering their social impact and poverty reduction, management system, financing, and financial performance. The review also covers the evolution of microfinance and the regulatory environment in Bangladesh.

This study investigates the possible impact of governance structure attributes to determine the attractiveness of a business entity and affects its ability to serve its customers and make a profit, using microfinance institutions (MFIs) from Bangladesh. Do these paper results show that MFB and MCPs hurt the financial performance of MFIs, and RDs have a positive effect if it augmented by gender diversity in management. The rest of the paper is organised as follows. Section 2 provides an overview of the extant literature on the governance of MFIs; Section 3 describes the research methodology; Section 4 contains the analysis of the impact of governance structure on MFI performance, and finally, Section 5 comprises some concluding remarks.

\section{Literature Review}

In Bangladesh, microfinance becomes an essential industry as the country is considered the origin of microfinance. The journey started with the concept of microcredit about 
four decades ago with the noble idea of Professor M. Yunus through MFB. The industry is composed of thousands of microfinance institutions (MFIs) that have been operating across the country aimed at poverty alleviation through increasing income and productivity of the borrowers (MRA, 2017). MFIs have covered about 60 per cent of the market. It is estimated that the industry serves more than 30 million poor people where it employs about two hundred thousand workers under different MFIs. Only eleven MFIs including MFB have 85 per cent of total servings (around BD Tk 426.68 Billion) and 81 of an entire outstanding loan (around BD Tk. 771.80 billion) of this microfinance sector (MRA, 2017). The authority is entitled to provide a license, set limits and investigate the performance of MFIs regularly. It is relevant to know the categorisation of MFIs, sources of funding and various models used by the MFIs in the industry.

Table 1. Common Microfinance Client Segments and Characteristics

\begin{tabular}{|c|c|c|c|}
\hline $\begin{array}{l}\text { Target Beneficiary } \\
\text { Segments }\end{array}$ & $\begin{array}{c}\text { Characteristics of Each } \\
\text { Segment }\end{array}$ & $\begin{array}{c}\text { Service Needs of the } \\
\text { Beneficiaries (financial } \\
\text { and non-financial } \\
\text { services) }\end{array}$ & $\begin{array}{l}\text { Common Strategy } \\
\text { Followed in Bangladesh }\end{array}$ \\
\hline $\begin{array}{l}\text { Hardcore poor } \\
\text { (Extremely poor or } \\
\text { ultra-poor) }\end{array}$ & $\begin{array}{l}\text { i) Daily calorie intake: } \\
\text { less than } 1800 \\
\text { ii) Land ownership: less } \\
\text { than } 0.15 \text { Acre } \\
\text { iii) Food deficit status: } \\
\text { Occasional to chronic } \\
\text { deficit }\end{array}$ & $\begin{array}{l}\text { Primarily savings } \\
\text { services; Starts with food } \\
\text { aid; skill training; and } \\
\text { minimal loans }\end{array}$ & $\begin{array}{c}\text { Skill training } \\
\text { Saving services } \\
\text { A small amount of loan } \\
\text { Food aid and asset } \\
\text { transfer }\end{array}$ \\
\hline Moderately Poor & $\begin{array}{l}\text { i) Daily calorie intake: } \\
\text { less than } 2112 \\
\text { ii) Land ownership: less } \\
\text { than } 0.5 \text { Acre } \\
\text { iii) Food deficit status: } \\
30-40 \% \text { above the } \\
\text { poverty line }\end{array}$ & $\begin{array}{l}\text { Savings and credit } \\
\text { services; } \\
\text { Flexibility in services } \\
\text { desirable; } \\
\text { Selective productive } \\
\text { skill training }\end{array}$ & $\begin{array}{l}\text { Savings and credit } \\
\text { services }\end{array}$ \\
\hline Marginal farmers & $\begin{array}{l}\text { i) Landownership: } \\
\text { less than } 1.5 \text { acres. } \\
\text { ii) Food deficit } \\
\text { status: break- even }\end{array}$ & $\begin{array}{l}\text { Agricultural extension } \\
\text { services; } \\
\text { Selective training on non- } \\
\text { crop income generating } \\
\text { activities; } \\
\text { Savings and credit } \\
\text { services. }\end{array}$ & $\begin{array}{l}\text { A limited number of } \\
\text { NGOs is in these market } \\
\text { segments; some } \\
\text { marginal farming } \\
\text { families included in } \\
\text { regular microfinance } \\
\text { groups. Savings and } \\
\text { credit service }\end{array}$ \\
\hline Small Farmers & $\begin{array}{l}\text { i) Landownership: } \\
\text { less than } 2.5 \text { acres. } \\
\text { ii) Food deficit: } \\
\text { surplus } \\
\text { iii) Normally no-- }\end{array}$ & $\begin{array}{l}\text { Agricultural extension } \\
\text { services; Training on } \\
\text { diversification in farming } \\
\text { and other areas and new } \\
\text { farming technologies; }\end{array}$ & $\begin{array}{c}\text { A few NGOs are } \\
\text { involved; mainstream } \\
\text { NGOs are yet to get } \\
\text { involved in this market } \\
\text { segment; limited }\end{array}$ \\
\hline
\end{tabular}




\begin{tabular}{|c|c|c|c|}
\hline $\begin{array}{l}\text { Target Beneficiary } \\
\text { Segments }\end{array}$ & $\begin{array}{c}\text { Characteristics of Each } \\
\text { Segment }\end{array}$ & $\begin{array}{c}\text { Service Needs of the } \\
\text { Beneficiaries (financial } \\
\text { and non-financial } \\
\text { services) }\end{array}$ & $\begin{array}{c}\text { Common Strategy } \\
\text { Followed in Bangladesh }\end{array}$ \\
\hline & poor & $\begin{array}{l}\text { Savings and credit (more } \\
\text { considerable and } \\
\text { seasonal loans); Access } \\
\text { to market and farm } \\
\text { inputs. }\end{array}$ & $\begin{array}{l}\text { savings and credit } \\
\text { services. }\end{array}$ \\
\hline Microentrepreneurs & $\begin{array}{l}\text { Managed by the } \\
\text { owner; less than ten } \\
\text { employees. } \\
\text { It is partly linked with } \\
\text { the mainstream } \\
\text { market. } \\
\text { May possess capital } \\
\text { machinery. } \\
\text { Investment usually } \\
\text { higher than income } \\
\text { generating activities; } \\
\text { Need more massive } \\
\text { loans. }\end{array}$ & $\begin{array}{l}\text { Credit services } \\
\text { (substantially larger: } \\
\text { USD 500-10 000) } \\
\text { Business } \\
\text { development } \\
\text { services } \\
\text { including access } \\
\text { to market and } \\
\text { product } \\
\text { development. }\end{array}$ & $\begin{array}{l}\text { Credit service similar } \\
\text { to regular } \\
\text { microcredit with } \\
\text { larger loan size. }\end{array}$ \\
\hline
\end{tabular}

Sources: (Alamgir, Hassan, \& Dewan, 2010), Alamgir 2009; MIDAS and ICG (2004); Wright and Alamgir (2004); McKennie and Rahman (2003).

\subsection{Prominent Microfinance Models}

The MFB (Grameen Model or Self-Help Group) is the first model to introduce the idea of Microcredit. As noted earlier, this model has been replicated by many other MFIs. Along with the concept of MFB, MCP has also introduced some unique features in providing financial services to the poor. Both types of model are popular and widely used in the country and even outside of Bangladesh. The third most popular model is RDS of IBBL which provides some services to the poor according to the shariah principle. The RDS also replicates some of the concepts of the MFB Model especially in its operational and lending methods although the models of operation and product of Islamic Microfinance are different.

\subsection{Microfinance Banking (MFB) Model}

Also known as the microfinance Banking model, the operation of this model based on a group-based credit approach. It targets the poorest of the poor. This group structure provides mutual support of its members and encourages group with strict discipline, allowing the borrowers to maintain good credit status and ensuring repayment in time. The system works based on trust. There is no written contract between MFB, and its 
borrowers 87 per cent of its members are women, and bank claims a loan recovery rate 99 per cent. Besides these things, MFB believes that charity is not an answer to poverty.

Yunus (2007) also emphasised to enlarge tools and services of financing that benefit the poor. Their outcomes and impacts were supposed to be carefully deliberated by institutions and system which work on development and poverty alleviation. As of now, MFB has 2568 branches in operation with nearly 9 million borrowers having an outstanding overall 93.15 per cent repayment rate.

Yunus (2008) says "microcredit is supposed to describe loans offered with no collateral to support income generating business aimed at lifting the poor out of poverty. He further suggests that the microcredit summit campaign which is a database of all microcredit programs should include only one type (poverty fighting) programs because only these contribute to the campaign's goal of using microcredit to help to eliminate poverty.

Indeed, microfinance's wide-reaching identification can be attributed to Muhammad Yunus, founder of MFB in Bangladesh. In 2006, the Nobel prize for peace was awarded to Muhammad Yunus and the MFB in the 1970s as an effort to address the multidimensional aspects of poverty. In the Nobel honorary reception, Professor Yunus says "I strongly believe that we can create hunger and poverty-free world if we collectively believe in it. In a poverty-free the world and the only place would be able to see poverty is in the poverty museums". As he believed that "the poor have an entrepreneurial drive and well equipped with survival skills that let them turn out a successful microentrepreneurs." These views of Yunus were further supported by Engler (2009).

More importantly, microfinance is a financial movement that tries to serve the poor because they are not capable of offering sufficient collateral. The traditional Banks and other financial institutions generally do not consider them creditworthy, but Muhammad Yunus, the founder of the MFB Bangladesh, proved that the poor are creditworthy and bankable. Indicates that credit will not be a new practice to the weakest members of the society as most of them borrow either from friends, relatives or local moneylenders. The UN Millennium project (2005) suggests that "microfinance is one of the practical development strategies, approaches that should be implemented, supported to attain the bold ambition of reducing world poverty by half." In light of the MFB model, the next sub-section examines how conventional microfinance is operational in Bangladesh.

\subsection{Micro-Credit Programme Model}

Since 1974, the micro-credit programme (MCP) started its credit operation which now becomes one of the largest MFIs, regarding loan coverage and clients. Its lending 
approach is almost similar to the MFB. Like many other MFIs, it has the goal which is to alleviate poverty through empowerment.

Bangladesh with its $42 \%$ people living below poverty line and $8.5 \%$ living in absolute poverty is suffering from acute rural-urban economic disparity and illiteracy, lack of proper health and sanitation facilities. The country's economy undoubtedly an agrarian one with the vast majority are living in village or rural areas. The agriculture sector and handicrafts are unable to provide any further scope for employment resulting in the influx of rural population towards urban areas. Stagnant agriculture and small industries characterise rural areas. Now underemployment and unemployment is a regular phenomenon, especially in rural areas. The vast human resources (HRM) have remained unutilized due to some lack such as (education, training, funding, and concerted efforts) to help grow the rural economy.

MFIs have undertaken many holistic approaches to alleviate poverty. The 'credit plus' is one of the methods through which borrowers enjoy the quality inputs, training and necessary support in marketing their products. Another approach is "Microloans" (Dabi), ranges from US\$100-US\$1,000, given to the borrowers. This type of loan usually disbursed for undertaking different income generating activities including fishing farm, poultry, livestock, fruit and vegetable cultivation, handicraft and other rural business. The loan repayment method is now more flexible that supports borrowers to repay their instalments is the monthly basis or weekly basis. From an economic viewpoint, this arrangement is cost effective for the institution also (Amin \& Author, 2011).

Another poverty alleviation scheme of MFIs-NGO is named as 'Progoti loan' (i.e., 'Progressive loan') ranges from US\$1,000- US $\$ 10,000$ that covers both male and female entrepreneurs. Indeed, these entrepreneurs are non-bankable and not qualified to receive a loan from the commercial bank for their small enterprises like grocery shops and smal1 scale manufacturing farms (Amin \& Author, 2011). MFIs-NGOs initiates a new step to reach out to the ultra-poor (who are suffering from chronic extreme poverty) and to help them in achieving the socio-economic developmental goal. The target population selected for providing them with various supports such as asset grant, skill training, healthcare service. Also, MFIs-NGOs forms village poverty reduction community to supervise and monitor the overall activities of the target group. Once the ultra-poor members have completed their assigned work in two-year grant phase, then they are allowed to join in the mainstream development program of MFIs-NGOs, and they enjoy wide ranges of financial services along with health care, human rights, and legal aids. (Amin \& Author, 2011). 


\subsection{Rural Development Scheme (RDS)}

Islamic microfinance a scheme in the name and style of Rural Development Scheme' (RDS) was first introduced to the investment needs of the agriculture sector and rural sector to create an opportunity for a generation of employment and raising the income of the rural people to alleviate poverty. In 1992, MFIs-NGOs introduced the Rural Development Program (RDP) mainly for the poverty alleviation in a rural area. The program is designed in a way to improve health condition and to provide mass education among the rural poor. The RDP has two wings, namely, income and employment generating a program for enhancing social development. Not only that, but the program also provides microcredit along with other support such as training facilities, raw material or input supplies and product marketing. These services are confined to only six particular sub-sectors, namely, fisheries, livestock, poultry, vegetable cultivation, sericulture, and social forestry.

In 1995, the Rural Development Scheme (RDS) established for ensuring equity, justice and employment opportunity for the rural people. The scheme is designed in a way to meet the investment needs of rural people, particularly in the agricultural sector. It supports them to get rid of poverty and to become self-reliant. It emphasises both farming and off-farming activities that not only create jobs but also enhance their incomes (Obaidullah, 2008).

Until now, the scheme is considered one of the largest Islamic Microfinance programs across the country (Chowdhury, 2007). According to a study, only 7\% of 1 million borrowers have access to financial services in Bangladesh (Bhuiya, 2006). This small group of borrowers has a better chance to receive Islamic Microfinance services from RDS not only due to its flexible terms and conditions of the loan but also due to low charge for a loan amount (Obaidullah, 2008).

The RDS maintains a mandatory savings provision where each member deposits Tk.10 per week under Mudarabah savings account. In case of urgency, the members are allowed to withdraw their accumulated savings if they are not indebted to the RDS. In addition to this saving arrangement, each member is required to contribute a minimum of Tk. 2.00 per week which is deposited as Mudarabah savings account under the name of the respective centre. By this, a pool saving created which is later used as Microinsurance to cover the unexpected loss of the borrowers due to accidents or sudden natural disasters (Islami Bank Bangladesh Limited, 2016).

The Bai-muajjal is the only mode of financing currently practised by RDS. Some other potential modes of financing like Mudharabah, ljarah, and Bai-salam are yet to be adopted (Islami Bank Bangladesh Limited, 2016). The individual group member requests 
for the financing in around eight weeks of the membership and the initial loan that he or she can get ranged between Tk. 8000-10,000 to until Tk. 30,000. Upon successful repayment of this category of loan, the members are then eligible to apply for a higher loan which is ranged between Tk.30,000 to Tk.200,000 under Microenterprise Investment Scheme (MEIS). Regardless of the type of loan, group members are required to pay off their total debts (principal amount with profit) in 44 equal instalments every week ((IBBL), 2016 \&Parvin et al., 2018).

The RDS emphasises on moral and spiritual aspects of the group members. These are implemented through various programs, for instance, a lesson on the social and religious responsibility to lead the lives in the Islamic way. Not only that, it inculcates many moral lessons among the members, a few of those are learning life honestly, performing good deeds, abiding by the law and abstaining from illegal work, selfreliance, working for prosperity, health consciousness, seeking knowledge through education. (Islami Bank Bangladesh Limited, 2016).

Table 2. Islamic Micro-finance Conceptual Model to achieve SDG

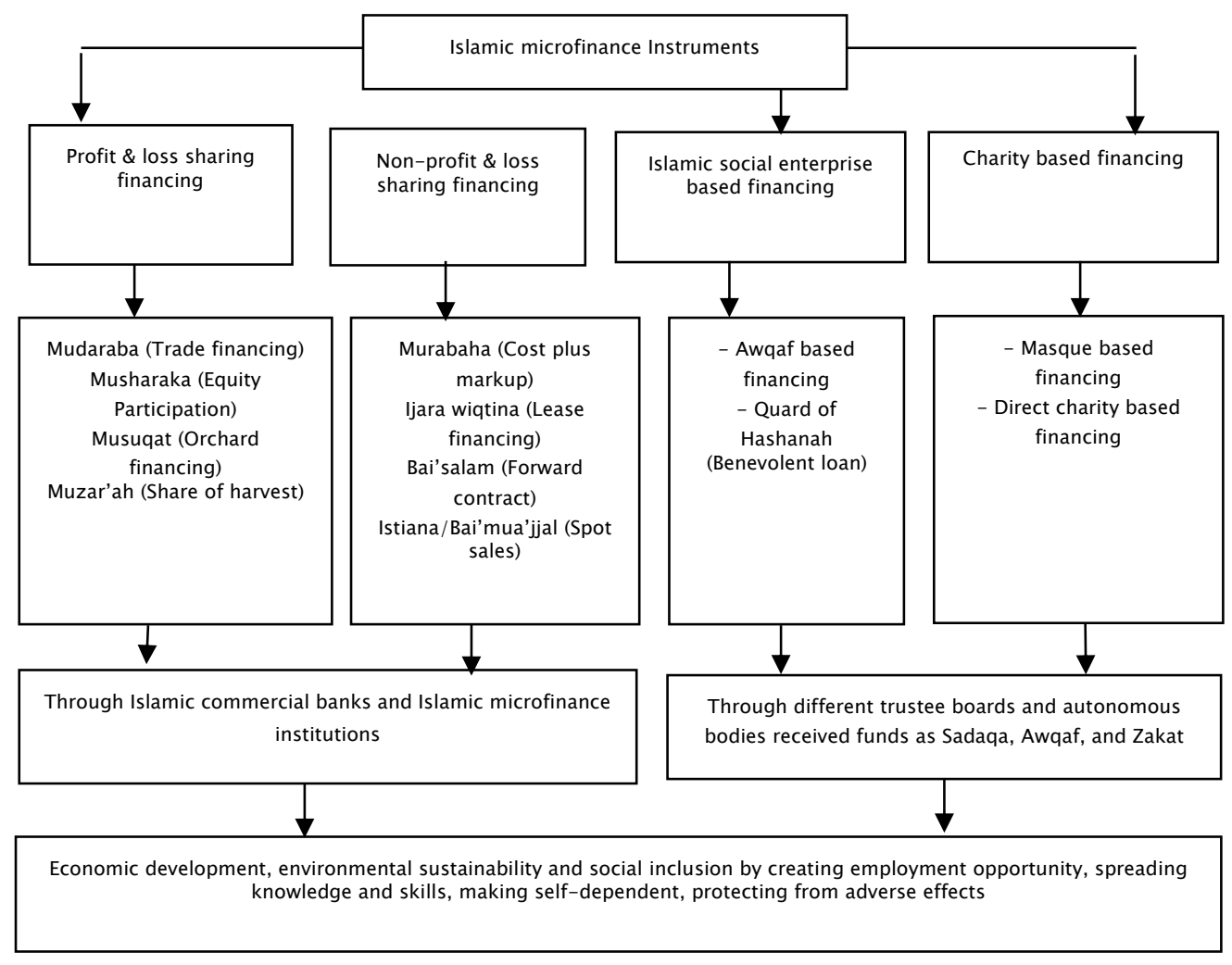




\section{Research Methods}

The principal of Porter's competitive strategy theory (1979) explains as to why it is incentive compatible for comparison, to design a pay structure for model and workers that partially based on performance. If it were possible to design a complete and comprehensive contract that covers future periods in a costless fashion, it would deem the competitive strategy theory redundant in providing a role for corporate governance structure and social impact.

According to Momanyi, Ragama, \& Kibati (2018), it explains how the study conceptualised, how data would be collected and analysed. Hence it does not only provide the philosophical basis for the study but also the practical roadmap. This study adopted a causal research design. The design was adopted because the study conceptualised in such a way that one thing causes another, such as good governance practices causing the social impact and poverty reduction of the industry. However, some institutions did not have available data while others were in the Grameen Bank, MCP, and RDS with microfinance divisions.

This study used secondary data, different techniques and approaches to data processing, analysis and presentation were applied. The techniques and approaches determined by the type of data collected. The analysis was mainly through descriptive statistics and inferential statistics.

This study focuses on the importance of governance structure such as social impact and , CEO (manager) and director (board member) remuneration, board structure (size and composition), auditing, information. Majority of MFls operate as non-profit organisations and are often accountable to multiple entities some of whom may not even fall under the traditional definition of a principal. While some competitive donor strategy requires transparent and stringent governance mechanisms, others require a nominal level of governance; most of the MFIs fall somewhere in between. On the other hand, many MFIs may also have internal motivation for highlighting an organisation with wellfunctioning governance to attract more funding by demonstrating their success. While the majority of the MFls registered as Non-Governmental Organizations (NGOs), a large number of MFIs registered as commercial banks, cooperatives, credit unions, nonbank financial institutions, or rural banks. MFIs depend on their donors for funds and the donors depend on MFI's for reputation and to some extent attaining their social goals (Hasan et al., 2018). 
This study investigates the possible impact of governance structure attributes to determine the attractiveness of a business entity and affects its ability to serve its customers and make a profit, using microfinance institutions (MFIs) from Bangladesh. These results show that MFB, MCPs hurt the financial performance of MFIs, and RDs have a positive impact if it is augmented by gender diversity in management.

\subsection{Conceptual Framework}

Table 3. Conceptual Framework

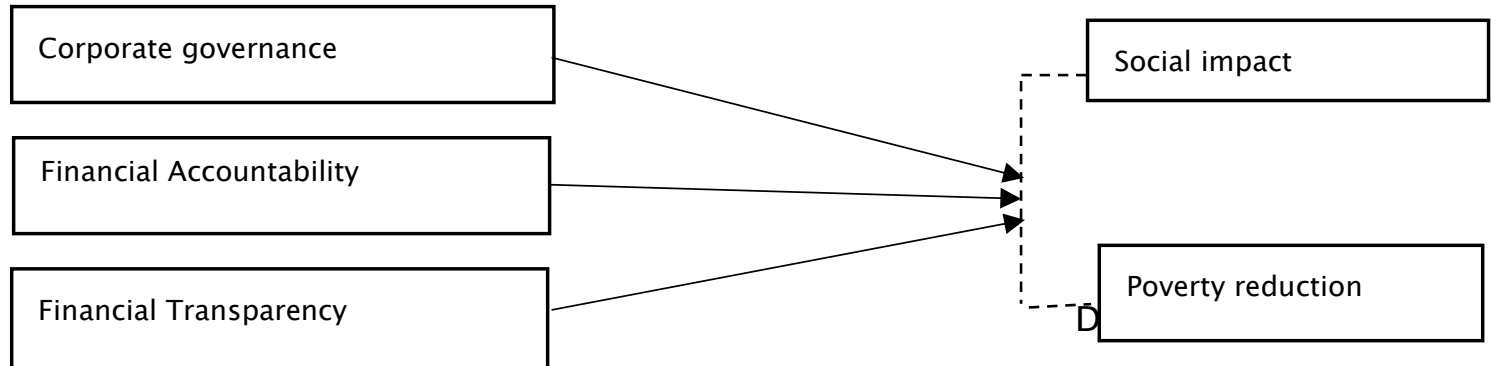

\section{Data Analysis and Interpretation}

The above discussion on three selected MFIs reveals that each of the institutions has a certain way of dealing with their borrowers. The principles of conventional MFIs are different from Islamic MFIs in many aspects. The practice of interest is the most distinctive feature in conventional MFIs whereas the principle of profit loss sharing is the key feature of Islamic MFIs. The following Table 4 presents the fundamental differences among the three MFIs under study.

Table 4: Micro-credit Regulatory Authority (MRA) June -2017

\begin{tabular}{|l|c|c|c|c|c|}
\hline Particulars & $\begin{array}{c}\text { Member } \\
\text { (Million) }\end{array}$ & $\begin{array}{c}\text { Borrowers } \\
\text { (Million) }\end{array}$ & $\begin{array}{c}\text { Amount of } \\
\text { loan } \\
\text { outstanding } \\
\text { (Tk. Billion) }\end{array}$ & $\begin{array}{c}\text { Amount of } \\
\text { Deposit } \\
\text { outstanding } \\
\text { (Tk. Billion) }\end{array}$ & $\begin{array}{c}\text { Loan } \\
\text { disbursement } \\
\text { (Tk. Billion) }\end{array}$ \\
\hline $\begin{array}{l}\text { Micro-credit Regulatory } \\
\text { Authority (MRA) }\end{array}$ & 29.9 & 25.98 & 583.82 & 216.71 & 1045.78 \\
\hline Grameen Bank NGO and & 7.14 & 7.14 & 134.58 & 191.02 & 207.85 \\
\hline $\begin{array}{l}\text { Government } \\
\text { Others }\end{array}$ & 1.52 & 1.12 & 24.2 & 11.23 & 29.66 \\
\hline $\begin{array}{l}\text { Government Bank and } \\
\text { Commercial Bank }\end{array}$ & 0.92 & 0.52 & 29.4 & 7.72 & 30.38 \\
\hline Total & 39.48 & 34.76 & 771.80 & 426.68 & 1313.67 \\
\hline
\end{tabular}


Before starting the discussion on microfinance institutions and their contributions to attainting social impact and poverty alleviation, this scenario is microfinance institutions in Bangladesh. Bangladesh is leading in microfinance institutions .it has a large number of NGOs that are involved in giving collateral -free credit to the poor and ultra-poor people. By providing microcredit, these NGOs have been able to reduce poverty in millions of families through a generation of own-orientated employment over the last couple of years. Microfinance institutions in Bangladesh gained pace after establishing the microcredit regulatory authority in 2006. The microfinance development in Bangladesh in recent years is summarised in Table 4. From Table 4, although the number member, borrowers, amount of loan outstanding, amount of deposit outstanding, loan disbursement in June 2017. Table 5 below shows more detailed information as regards to MFB (Grameen Model), MFIs (Microcredit model) and RDS in IBBL show in the following table.

The study focuses on the success and failure factors MFB Grameen Model, MFIs and RDS in IBBL. In their comparative analysis, we show that the overall governance structure of RDS is relatively better than the rest others regarding growth, repayment rate, charging fees, operational efficiency, accountability, and transparency. For example, the annual growth rate of RDS is 12.57 per cent while this rate is around 7 per cent in the case of both MFB and MFIs. The RDS is relatively new in the Microfinance Industry in Bangladesh compare with MFB and MFIs. However, the scheme is getting popular among the borrowers who have the firm belief in Islamic morals and values.

Table 5. Features of Three Microfinance Programs

\begin{tabular}{|l|c|c|c|}
\hline Program Features & Microfinance Banking & Microfinance Institutions & $\begin{array}{c}\text { Rural Development } \\
\text { Scheme }\end{array}$ \\
\hline Membership Criteria & $\begin{array}{c}\text { Minimum half of an acre } \\
\text { of land. Members } \\
\text { selected through a } \\
\text { means test. }\end{array}$ & $\begin{array}{c}\text { Day labour is working } \\
\text { for a wage and has a } \\
\text { maximum of half an acre } \\
\text { of land. }\end{array}$ & $\begin{array}{c}\text { Must have at least half } \\
\text { acre of land. Members } \\
\text { are selected with a strict } \\
\text { means test. }\end{array}$ \\
\hline Group Features & $\begin{array}{c}\text { Five members in a } \\
\text { group and five to eight } \\
\text { groups (25-40 } \\
\text { members) constitute a } \\
\text { centre. }\end{array}$ & $\begin{array}{c}\text { 30-40 members form a } \\
\text { village organisation (VO), } \\
\text { Vos is split into } \\
\text { solidarity groups for } \\
\text { men and women. }\end{array}$ & $\begin{array}{c}\text { Five members in a group } \\
\text { and } 2 \text { to } 6 \text { groups } \\
\text { constitute a centre. }\end{array}$ \\
\hline Group Meeting & $\begin{array}{c}\text { Weekly are meeting of } \\
\text { groups. }\end{array}$ & $\begin{array}{c}\text { Weekly are meeting of } \\
\text { solidarity groups. }\end{array}$ & $\begin{array}{c}\text { Weekly are meeting of } \\
\text { groups. }\end{array}$ \\
\hline Regulation of Services & $\begin{array}{c}\text { Group members are } \\
\text { responsible for } \\
\text { repayment. }\end{array}$ & $\begin{array}{c}\text { Group approach is not } \\
\text { compulsory }\end{array}$ & $\begin{array}{c}\text { Group members are } \\
\text { morally responsible and } \\
\text { religiously motivated }\end{array}$ \\
\hline
\end{tabular}




\begin{tabular}{|c|c|c|c|}
\hline Program Features & Microfinance Banking & Microfinance Institutions & $\begin{array}{c}\text { Rural Development } \\
\text { Scheme }\end{array}$ \\
\hline Funding & Self-funding & $\begin{array}{c}\text { NGOs, Donors supply } \\
\text { the funds }\end{array}$ & $\begin{array}{c}\text { From IBBL, charity, IBBL } \\
\text { Foundation }\end{array}$ \\
\hline Saving Mobilization & $\begin{array}{c}\text { Compulsory IS saving of } \\
\text { Taka one per week. }\end{array}$ & $\begin{array}{c}\text { Compulsory is saving of } \\
\text { Taka two per week. }\end{array}$ & $\begin{array}{c}\text { Compulsory is a weekly } \\
\text { saving of Tk.10. }\end{array}$ \\
\hline $\begin{array}{l}\text { Credit Delivery } \\
\text { Mechanism }\end{array}$ & $\begin{array}{l}\text { Group liability acts as } \\
\text { social collateral where } \\
50 \text {-week instalment of } \\
\text { the loan }\end{array}$ & $\begin{array}{l}\text { Group liability acts as } \\
\text { social collateral where } \\
50 \text {-week instalment of } \\
\text { the loan }\end{array}$ & $\begin{array}{l}\text { Group liability acts as } \\
\text { social collateral where } \\
\text { 44-week instalment of } \\
\text { the loan }\end{array}$ \\
\hline Target Group & Mainly poor women & Poor households & $\begin{array}{l}\text { Poor women through } \\
\text { family }\end{array}$ \\
\hline Type of Loan & $\begin{array}{l}\text { Small and medium-size } \\
\text { loan }\end{array}$ & $\begin{array}{c}\text { Small loans for short } \\
\text { duration }\end{array}$ & $\begin{array}{l}\text { Small and medium-size } \\
\text { loan }\end{array}$ \\
\hline Training & $\begin{array}{c}\text { Duration was of training } \\
\text { s between } 15-30 \text { days. } \\
\text { Leased skills-based } \\
\text { training }\end{array}$ & $\begin{array}{l}\text { Duration of training } \\
\text { ranged between 3-6 } \\
\text { months substantial } \\
\text { skills-based training. }\end{array}$ & Not provided \\
\hline
\end{tabular}

Source: Grameen Bank, Microcredit Regulatory Authority (MRA) \& RDS in IBBL.

\subsection{Microfinance Banking Model}

Grameen Bank: The capital structure of the Grameen Bank is unique, that is, similar to that of a commercial bank, which currently social impact is a total number of branches 2568. Number of members 8.93 million, active borrowers 7.23 million, number of active borrowers per branch end of the years 2814. Moreover, number loan officers 11922 , women member is 96.65 per cent and average loan balance per borrower BDT 19,977 in 2017. This structure has been possible due to its legal coverage as a bank to raise savings as well as additional permission from the government to offer various savings services. The deposits of the bank come from members' savings (various short and longterm deposits), deposits of staff members and deposits from other sources. No other MFI in the country has such legal basis, an array of savings services as well as dependence on deposits to finance microfinance operations. That is, Return on equity (ROE) IS 1 7.09\% was last year, but it is not constant. Moreover, operating self-sufficiency (OSS) and financial self-sufficiency (FSS) is $106.92 \%$ and $103.42 \%$. Additional insights can be obtained from Table 6 below which provides a comparative sheet of Grameen Bank for 2013 to 2017 [Grameen Bank 2017]. That is, the bank is financed from internally generated resources. Grameen Bank has benefited enormously from its legal position compared to other MFIs, being the only MFI legally able to offer long-term savings products to its members and to take savings from the public. Besides, not many MFIs give the poor people access to their savings and pay good interest on savings other than Grameen Bank. 
Table 6. Comparative Sheet of Grameen Bank

\begin{tabular}{|c|c|c|c|c|c|c|}
\hline \multicolumn{7}{|c|}{ Social Impact } \\
\hline \multicolumn{2}{|c|}{ particulars } & 2013 & 2014 & 2015 & 2016 & 2017 \\
\hline 1 & Number of branches & 2,567 & 2,568 & 2,568 & 2,568 & 2,568 \\
\hline 2 & $\begin{array}{l}\text { Number of members (In } \\
\text { millions) }\end{array}$ & 8.54 & 8.64 & 8.81 & 8.90 & 8.93 \\
\hline 3 & $\begin{array}{l}\text { Number of active borrowers (In } \\
\text { millions) }\end{array}$ & 6.74 & 7.03 & 7.18 & 7.29 & 7.23 \\
\hline 4 & $\begin{array}{l}\text { Number of active borrowers per } \\
\text { branch (year-end) }\end{array}$ & 2,625 & 2,739 & 2,796 & 2,837 & 2,814 \\
\hline 5 & Number of loan officers & 12,826 & 12,800 & 12,734 & 12,279 & 11,922 \\
\hline 6 & Percent of women members & $96.21 \%$ & $96.26 \%$ & $96.51 \%$ & $96.54 \%$ & $96.65 \%$ \\
\hline 7 & $\begin{array}{l}\text { Average loan balance per } \\
\text { borrower (Taka) }\end{array}$ & 12,522 & 12,438 & 13,427 & 16,230 & 19,997 \\
\hline \multicolumn{7}{|c|}{ Poverty reductions } \\
\hline 1 & Return on equity (ROE) & $13.65 \%$ & $4.15 \%$ & $0.22 \%$ & $11.82 \%$ & $17.09 \%$ \\
\hline 2 & Operating self-sufficiency (OSS) & $105.15 \%$ & $101.53 \%$ & $100.08 \%$ & $104.53 \%$ & $106.92 \%$ \\
\hline 3 & Financial self-sufficiency (FSS) & $99.59 \%$ & $96.51 \%$ & $95.80 \%$ & $101.23 \%$ & $103.42 \%$ \\
\hline
\end{tabular}

Source: Grameen Bank Annual Reports for various years

Commercial Banks: The formal Banking sector comprises four categories of organisations: the state-owned banks (nationalised commercial banks (NCBs)) namely Sonali, Agrani, Janata, and Rupali Banks; six specialised; private banks; and foreign (commercial) banks. Following the success of Grameen Bank, the four NCBs and two agricultural banks started to offer local microcredit by replicating group-based management technology, in addition to their small loans for agricultural as well as other purposes. Invariably all such group-based programs managed directly by the bank staff members have collapsed with huge default of loans. Currently, NCBs have largely abandoned lending to group-based small loan programs but have maintained their original individual loan operations. Commercial banks, state-owned and private, are offering 'wholesale loans' to MFIs at interest rates varying between 10-15\%. The exception is IBBL, which has sizeable retail microfinance operations as described below in this paper.

\subsection{Rural Development Scheme (RDS) in Bangladesh}

Total rural development scheme clients in the whole world are approximately 1 million, more than half of them are in Bangladesh, and over 80 per cent of them are involved in Bangladesh, Indonesia, and Afghanistan. Islamic microfinance market comprises of 6 Islamic banks, 20 small Islamic microfinance institutions (IMFIs) and Islamic microfinance program of a conventional MFI. Association of Muslim Welfare Agencies in Bangladesh (AMWAB) works as a wholesale fund provider to a limited scale(Uddin, 2018). Islamic 
banks are regulated by Bangladesh Bank, Central Bank of Bangladesh while Islamic microfinance institutions (IMFIs) have licenses from Micro Credit Regulatory Authority (MRA), the watchdog of microfinance in Bangladesh. Islami Bank Bangladesh Limited (IBBL), the first Islamic bank in South Asia is the largest provider of Islamic microfinance in Bangladesh accounting for 78.84 per cent share of Islamic microfinance market (Nabi et al. Uddin, 2018). Islamic microfinance institutions in Bangladesh usually use deferredpayment sales (bay mu'ajjal) mode of financing that is facing a massive competition with conventional NGO from Table 7.

Table 7. Scenario of Islamic Microfinance in Bangladesh (2017)

\begin{tabular}{|l|c|c|c|}
\hline Provider of IMF & $\begin{array}{c}\text { Number of } \\
\text { Clients(Million) }\end{array}$ & $\begin{array}{c}\text { Yearly Loan } \\
\text { disbursement(BDT } \\
\text { in Billion) }\end{array}$ & $\begin{array}{c}\text { Outstanding of Loan } \\
\text { ( BDT in Billion) }\end{array}$ \\
\hline Islami Bank Bangladesh Limited & 0.947 & 29.92 & 20.80 \\
\hline Al Arafah Islamic Bank Limited & 0.050 & 3.52 & 0.66 \\
\hline First Security Islami Bank Limited & 0.004 & 0.10 & 0.08 \\
\hline Social Islamic Bank Limited & 0.0007 & 0.01 & 0.01 \\
\hline Islamic NGOs/ MFIs( 20)* & 0.220 & 4.17 & 2.77 \\
\hline Conventional NGO with Islamic & 0.005 & 0.23 & 0.03 \\
\hline Microfinance (1)* & 1.70 & 37.95 & 24.36 \\
\hline Total & & & \\
\hline
\end{tabular}

Source: (i) Respective Islamic banks, (ii) Association of Muslim Welfare Associations Bangladesh (AMWAB) and (iii) TMSS- Only conventional NGO with Islamic microfinance program. * Provisional data.

\subsection{The Social Impact of Rural Development Scheme up to 2017}

Islami Bank Bangladesh Limited launched its journey of Rural Development Scheme in 1995. In the meantime, $350+$ branches of the bank have been performing their activities of the scheme in their respective areas. About 18,615 villages have been covered by the scheme were 9, 47,305 members have been involved. The members have been provided investment facilities an amount of BDT 1, 30,445.12 million having outstanding BDT $20,798.82$ million where members saving is BDT 6,490. The recovery rate of the scheme is approximately $99.59 \%$ Table 8.

Islami Bank Bangladesh Limited is offering a vast dimension in Investment arena for RDS throughout the country. The investment and saving scenario of IBBL that have been increasing day by day since launching the scheme. This increased investment phenomenon is contributing a lot to the up economic gradation of the poor-trodden people of the country. 
Table 8. Social impact of Rural Development Scheme June 2017

\begin{tabular}{|l|l|l|}
\hline SI. & Area of performance & No. \& Volume/ Amount \\
\hline 01 & No. of Branches handling the scheme & $350+$ \\
\hline 02 & No. of Villages & 18,615 \\
\hline 03 & No. of members & $9,47,305$ \\
\hline 04 & Cumulative disbursement & BDT(Million) 130445.12 \\
\hline 05 & Current Outstanding & BDT(Million) 20798.82 \\
\hline 06 & Members savings & BDT(Million) 6890 \\
\hline 07 & Share in IBBL'S total investment & $3.64 \%$ \\
\hline 08 & Rate of Recovery & $99 \%$ \\
\hline 09 & No. of women members & $85 \%$ \\
\hline
\end{tabular}

\subsection{Microfinance Model}

The capital structure of the NGO is unique, that is, similar to that of a non-banking financial institution, which currently social impact is some branches 17,120 . Number of members 29.9 million, active borrowers 24.85 million, number of employees 139526 .moreover Loan Disbursement 1045.78 billion, Amount of Loan Outstanding 583.62 billion, Agri Loan Disbursement 408.87 billion, Agri Loan Outstanding 354.00 billion, Amount of Savings 216.71, Loan Recovery 876.85 billion in 2017. This structure has been possible due to its legal coverage as an MFIs-NGO to raise savings as well as additional permission from the government to offer various savings services. The deposits of the MFIs -NGO come from members' savings (various short and long-term deposits), deposits of staff members and deposits from other sources. No other MFI in the country has such legal basis, an array of savings services as well as dependence on deposits to finance microfinance operations.

Table 9. Microfinance sector of Bangladesh (Basic Activities)

\begin{tabular}{|l|l|l|l|l|l|l|}
\hline Particulars & $\begin{array}{l}\text { June, } \\
2012\end{array}$ & $\begin{array}{l}\text { June, } \\
\mathbf{2 0 1 3}\end{array}$ & $\begin{array}{l}\text { June, } \\
\mathbf{2 0 1 4}\end{array}$ & $\begin{array}{l}\text { June, } \\
\mathbf{2 0 1 5}\end{array}$ & $\begin{array}{l}\text { June, } \\
\mathbf{2 0 1 6}\end{array}$ & $\begin{array}{l}\text { June, } \\
2017\end{array}$ \\
\hline $\begin{array}{l}\text { No. of Licensed NGO- MFIs (Provided valid } \\
\text { data) }\end{array}$ & 590 & 649 & 742 & 753 & 758 & 655 \\
\hline No of Branches & 17,977 & 14,674 & 14,730 & 15,609 & 16,284 & 17,120 \\
\hline No. of Employees & 108,654 & 110,734 & 109,628 & 110,781 & 127,820 & 139526 \\
\hline No. of Clients (Million) & 24.64 & 24.60 & 25.11 & 26.00 & 27.79 & 29.9 \\
\hline Total borrowers (Million) & 19.31 & 19.27 & 19.42 & 20.35 & 23.28 & 24.85 \\
\hline Loan Disbursement (Tk. Billion) & 456.02 & 432.28 & 462.00 & 634.00 & 787.00 & 1045.78 \\
\hline Agri Loan Disbursement (Tk. Billion) & 110.84 & 131.98 & 155.73 & 266.25 & 353.00 & 408.87 \\
\hline Amount of Loan Outstanding (Tk. Billion) & 211.32 & 257.01 & 282.20 & 352.41 & 459.37 & 583.62 \\
\hline
\end{tabular}




\begin{tabular}{|l|l|l|l|l|l|l|}
\hline Particulars & June, & June, & June, & June, & June, & June, \\
& 2012 & 2013 & 2014 & 2015 & 2016 & 2017 \\
\hline Agri Loan Outstanding (Tk. Billion) & 66.71 & 89.05 & 115.77 & 147.60 & 285.00 & 354.00 \\
\hline Amount of Savings (Tk.Billion) & 75.25 & 93.99 & 106.99 & 135.41 & 171.19 & 216.71 \\
\hline Loan Recovery (Tk. Billion) & 314.11 & 375.07 & 447.89 & 522.47 & 773 & 876.85 \\
\hline Recovery Rate & 97.74 & 97.69 & 95.64 & 96.02 & 95.9 & 96.5 \\
\hline
\end{tabular}

Data Source: MRA-MIS 2017 and Authors.

\subsection{Empirical Studies on MFB, MFI, RDS}

In the study Badan Kredit Kecamatan (BKK), Kredit Usaha Rakyat Kecil (KURK or credit for activities of the poor in East Java), Bank Rakyat Indonesia (BRI) in Indonesia, Regional Rural Banks in India, Grameen Bank in Bangladesh, BRAC, Thana Resource Development \& Employment Programme (TRDEP) in Bangladesh and Primary Thrift and Credit Cooperative Society (PTCCS) in Sri Lanka. It shows that borrowers' income always increases due to their participation in outreach and governance.

Khandker (2005) focuses on the MFB, MFI, and RDs and shows that households who are poor in landholding and have formal education tend to participate more in the program, and microfinance program is much useful in reducing extreme poverty than moderate poverty. Besides, the welfare effect of the program's participation is also positive for all households, including non-participants due to the spillover effects.

While studying the case of MFI and MFB in Bangladesh, confirm that the borrower's income is significantly related to certain variables, i.e., land holding size, total yearly employment, amount of loan, days suffered from morbidities; the number of times loan taken, family labour; length of membership and length of training. Moreover, regression analysis shows that three variables such as family labour positively relate the income of the NGO beneficiaries, the days worked in a year and land holding size, which the factor days are holding size, while the factor days suffered from morbidities impacted negatively.

It was that NGO membership length, times, and a loan taken has no impact on their income rather than an increase in the amount of land asset, employment, family labour and reducing morbidities enhance family income. These findings are posing the question on the actual contribution of MFIs towards poverty alleviation through to economic development. However, few others exhibit the positive effect of MFIs on poverty alleviation in the long run. 
Some others show that both MFB and MFI are contributing to the poverty alleviation by adopting different approaches. Grameen Bank (GB) provides a loan to the group members and this supply of capital used for agricultural and non-agricultural activities which generate more income and thus help increase consumption in the long run. Due to the difference of the repayment system, BRAC's member enjoys much flexibility than GB's member. That is why to increase income and consumption; it takes a more extended period in the case of GB comparing to NGO. The study finding demonstrates that NGO is efficiently utilising its resources than GB. Hence, MFIs-NGO is comparatively ahead of poverty alleviation; however, if the institution does not find a way to improve its economic performance, its action will not be sustainable in the long run. For MFB, they suggest that it needs to increase the training for its members and to exploit other sectors of self-employment.

Ahmed (2008) makes the differences between MFB and RDS concerning their programs and operations. The study focuses on institutional aspects in Microfinance operation with the help of secondary data. It identifies a few limitations of GB, for instance, not to give loans to the landless or hardcore poor people, make excessive profit margin which is $54.95 \%$ compared with other businesses like retailers, manufacturers and commercial banking where their profit margins are $15 \%-25 \%, 10 \%-15 \%$ and $14 \%-16 \%$, respectively. In contrast, the rate of return (lending cost of the borrowers) of RDS is only $10 \%$ against its various investment schemes. Also, it introduces a $2.5 \%$ rebate on timely repayment of the loan. Besides, RDS provides special cash fund to the borrowers during the time of natural calamities. It has been shown that $25 \%$ of GB's borrowers are inclined to switch the program to RDS due to the high rate of interest and the extra pressure of weekly repayment system.

An indebt analysis shows that RDS has the lowest lending or investment rate (i.e., 10\%), the highest growth rate (i.e., 12.57\%) and the lowest dropout rate (i.e., 5\%) and the highest loan repayment rate (99\%) among MFIs and MFB. The study focuses more on the operational aspects of RDS where it argues that field officers do not follow any harsh rule during the collection of outstanding instalments. Besides, due to a natural disaster or other uncertainty, affected borrowers enjoy special rebate or wave of some instalments until their financial recoveries (Parvin et al., 2018).

Bhuiyan et al. (2011) in their study focus on the impact of microcredit on the household income of MFB and RDS. It reveals that the microcredit contributed positively to the income level of the borrowers of both MFIs; however, the average monthly income of RDS's households is higher than that of MFB's households. Besides, households from 
both institutions have successfully been able to increase their income levels by more than $50 \%$. However, the RDS borrowers utilise the loan amount more effectively than others. Furthermore, $42 \%$ of GB's respondents and $31.8 \%$ of RDS's respondents used to spend their loan amount for consumption purpose. These findings are quite astounding because borrowers' incomes are increasing in one hand and their loan amounts are being spent on consumption purposes or unproductive actives on the other hand. Nevertheless, the study confirms the substantial and significant positive relationship among demographic, socio-economic factors with a total household income of both MFB and RDS. It is recommended that both intuitions should emphasise on income generating activities, a supply of sufficient loan, increase the period of instalment of payment, provide necessary training, and above all utilise the Zakat and Qardhasan institution for strengthening the poverty alleviation in Bangladesh.

Another study mentions a few other challenges of RDS such as sponsorships investments, resources, and mechanisms, lack of understanding in differentiating interest and profit. Can lead to failure of the scheme. Besides, many borrowing in another most critical challenge for MFIs, also, it is hazardous for the clients who get trapped on the various debts and fall under permanent poverty cycles. Therefore, the problems of fund inadequacy must be resolved for the practical result of MFIs.

\subsection{The Social Impact and Poverty Reduction of the Microfinance Program}

The findings of social impact and poverty reduction studies vary from the nature and context of the MFIs. Some studies find strong pieces of evidence on the social impact and poverty reduction of the Microfinance Institutions (MFIs) on Poverty alleviation while few others also observe some flaws of the MFIs which are the impediments to the poverty reduction. The different results may also due to the inadequacies of the research designs and inappropriate research techniques. It studies fail to meet the appropriate research should include more rigorous statistical analysis with proper research methodology: the social impact and poverty reduction regarding selecting a sample, location, and the control research framework (Morduch, 1998). Thus, the findings of the social impact and poverty reduction of particular MFIs not only depend on the proper research design and technique, but it also depends on the location, time and other factors.

In Bangladesh, numerous studies conducted in Microfinance which have found a positive impact on improving borrowers' capacity to generate income, and also help to enhance their households incomes, fixed assets, net working capital, spending on food and medical facilities and children's schooling. These studies mostly observe the impact of 
Microfinance program on household incomes and assets only. However, the weakness of these studies is not to address the effectiveness of the program.

MFIs impacts positively as the participants can afford health care and even to educate their children up to a higher level. Hence, the program makes the participants both physically and economically active which are the necessary conditions for poverty alleviation. In another study, it shows that MFIs can also build up the dignity and the self-confidence among the participants.t also impact positively on their loan repayment performances and sustainable incomes.

The MFIs are social impact and poverty reduction particularly in a place or area where it is tough to get a loan from the NGO financial institution, and the rate of interest is high. Hence, MFIs are designed in such a way that the borrowers have easy access to a loan with a low rate of interest. For instance, 5 per cent of the total participants of both MFB and MFIs-NGO get rid of poverty annually. Moreover, the MFIs are found thriving in an environment where loans are sanctioned to those who have entrepreneurial skills. It is found that 42 per cent of the total of GB's members has successfully been able to cross the poverty line.

A study on MFB, MFIs-NGO, and RDs confirm the usefulness of MFIs regarding reaching the poor. However, the programs are found social impact and poverty reduction in reaching the hardcore or vulnerable poor (Amin \& Author, 2011). Similarly, BRAC's MFI has a positive impact on human well-being, schooling of children and the survival rate of group members. Khandker (2005), in his subsequent research, demonstrates that MFIs is adequately addressing the issue of poverty as the program facilitates the individual borrowers and households to enhance their incomes, health care, nutrition, empowerment, and education. Thus, they get rid of poverty and hunger and move on to a higher standard of living. Nevertheless, measuring the outreach and sustainability of MFIs would be more appropriate if some other factors such as interest rate, loan size and use of loan were included in the studies.

RDS is becoming accessible and useful because of practising moral and spiritual values among the group members and the field staff. It leads borrower to generate higher income, saving, reduction of production cost and family expenditure. MFIs have a crucial role in upgrading the livelihood of rural inhabitants. He suggests that even with the assistance of MFIs, the agricultural sector can be developed where rural people mostly rely on their jobs. Some factors such as technological advancement, infrastructural 
development, and fair market arrangement can change the agricultural sector, and MFIs have a pivotal role to play.

The poor are hardworking and innovative, so they need decent options to apply their skills and qualifications in conducting businesses. Although in some cases MFIs are charging high-interest rate compare with the conventional financial institution, the borrowers used to get loans and maintain good repayment performances which lead them to success in various petty businesses.

The author applies qualitative and quantitative analysis to justify the efficiency of Microfinance operations. The result indicates that MFIs has a positive effect on borrowers (those who have joined the program for at least three years) regarding household incomes and expenditures. Also, borrowers have been able to intersect the extreme poverty line, but they are yet to cross the moderate poverty line. Besides, the MFI has created employment opportunities to enhance the income levels of the borrowers. However, the impact of the program on the borrowers' savings and the conditions of dwelling houses are found insignificant.

\section{Conclusion}

This study finds that the pressure to earn commercial profits has weakened the poverty alleviation agenda for most MFBs and MFIs. RDs, in comparison, appear more committed to their social mission. Part of the reason is that MFIs are operationally more flexible and can keep their operational costs low, thanks to fewer regulatory requirements, which allows them to expand outreach to more indigent clients, who are in general more expensive from the institutional point of view. However, the findings also suggest that the distinctions between the two institution types are in no small extent policy driven.

MFIs have become more committed to achieving financial sustainability. It has meant that most MCPs and MFBs now target the less poor or even the non-poor; most MFBs and some MFIs do not lend to start-ups. At least one MFI asks its borrowers to pay a few days ahead of the actual due date so that repayment rates can look good, and most MFBs have stepped up lending against gold - a clear departure from the original noncollateralized microfinance model.

The study finds RDs, a zero interest based MFI, to be the sector's clearest outlier. It mainly seeks social change and poverty alleviation and has little interest in becoming commercially viable. However, there are other institutions the poverty alleviation agenda takes precedence over finding financial returns. 


\section{Reference}

Ahmed, M. (2008). Grameen Bank vs. RDS of IBBL: A Comparative Analysis. Bangladesh Journal of Islamic Thought, BIIT, 4, 5.

Akter, A., Ahmad, N., Jaafar, W. M. W., Zawawi, D. B., Islam, M. M., \& Islam, M. A. (2018). Empowerment of Women through Entrepreneurial Activities of Self-Help Groups in Bangladesh. Journal of International Business and Management, 1(1), 1-15.

Alamgir, D. A., Hassan, M. K., \& Dewan, H. H. (2011). A comparative review of Islamic versus conventional microfinance in Bangladesh. In 8 the International Conference on Is/amic Economics and Finance, Qatar National Convention Center (pp. 19-21).

Ali, I., Hatta, Z. A., Azman, A., \& Islam, S. (2017). Microfinance as a development and poverty alleviation tool in rural Bangladesh: A critical assessment. Asian Social Work and Policy Review, $17(1), 4-15$.

Alom, M. M., \& Haque, M. S. (2011). Marketing: An Islamic Perspective. World Journal of Social Sciences, 1(3), 71-81.

Amin, R., \& Author, C. (2011). The impact of the Micro-finance program on the poor: A Comparative study of Grameen Bank, BRAC, and ASA in some selected areas in Bangladesh. Journal of Business and Management, 3(4), 346-364.

Azad, M. A. K., Masum, A. K. M., Munisamy, S., \& Sharmin, D. F. (2016). Efficiency analysis of major microfinance institutions in Bangladesh: a Malmquist index approach. Quality and Quantity, 50(4), 1525-1537. https://doi.org/10.1007/s11135-015-0219-8

Baklouti, I. (2013). Determinants of microcredit repayment: The case of Tunisian microfinance bank. African Development Review, 25(3), 370-382. https://doi.org/10.1111/j.14678268.2013.12035.x

BRAC. (2015). 2015 Annual Report. Retrieved from http://www.brac.net/images/reports/BRACBangladesh-Report-2015.pdf

BRAC. (2016). BRAC Annual Report 2016, 54.

D'Espallier, B., Goedecke, J., Hudon, M., \& Mersland, R. (2017). From NGOs to banks: Does institutional transformation alter the business model of microfinance institutions?. World Development, 89, 19-33.

Grameen Bank. (2017). Annual Report 2016, 88.

Haq, M., Skully, M., \& Pathan, S. (2010). The efficiency of microfinance institutions: A data envelopment analysis. Asia-Pacific Financial Markets, 171), 63-97. https: / / doi.org/10.1007/s10690-009-9103-7

Hasan, T., Quayes, S., \& Khalily, B. (2018). Role of governance on the performance of microfinance institutions in Bangladesh. Eurasian Economic Review. https://doi.org/10.1007/s40822-0180102-8

Hartarska, V. (2005).Governance and performance of microfinance institutions in Central and Eastern Europe and the newly independent states. World development, 33(10), 1627-1643.

Hermes, N., Lensink, R., \& Meesters, A. (2011). Outreach and Efficiency of Microfinance Institutions. World Development. https://doi.org/10.1016/j.worlddev.2009.10.018

Islam, M. T. (2018). Social justice: The rural development scheme (RDS) in Bangladesh. International Journal of Islamic Thoughts (IJTS), $7(1)$. 
Islami Bank Bangladesh Limited, I. (2016). Annual Report 2016 : Consolidating Strength Fostering Progress.

Jaiyeoba, H. B., Adewale, A. A., \& Ibrahim, K. (2018). Measuring efficiencies of Bangladeshi and Indonesian microfinance institutions: A data envelopment analysis and latent growth curve modelling approach. International Journal of Bank Marketing, 36(2), 305-321.

Khandker, S. R. (2005). Microfinance and poverty: Evidence using panel data from Bangladesh. World Bank Economic Review, 19(2), 263-286. https://doi.org/10.1093/wber/lhi008

Mia, M. A. (2017). An overview of the microfinance sector in Bangladesh. The East Asian Journal of Business Management, 7(2), 31-38.

Momanyi, J., Ragama, P., \& Kibati, P. (2018). Effects of corporate governance practices on the growth of microfinance institutions in Kenya. International Journal of Economics, Commerce and Management United Kingdom (Vol. Vl). Retrieved from http://ijecm.co.uk/

MRA. (2016). NGO-MFIS in Bangladesh: A Statistical publication.

Nawaz, A., Iqbal, S., \& Ehsan, S. (2018). Does Social Performance Drive Corporate Governance Mechanism In Case of Asian MFIs? An Issue of Endogeneity. Clobal Business Review, 19(4), 9881012. https://doi.org/10.1177/0972150918772961

Obaidullah, M. (2008). Role of microfinance in lessons from experiences in selected poverty alleviation idb member countries lessons from experiences in selected IDB member countries.

Parvin, S. S., Mohiuddin, M., Hoque, A., \& Su, Z. (2018). Financial Sustainability of NonGovernmental Microfinance Institutions (MFIs ): Review of Economics \& Finance Financial Sustainability of Non-Governmental Microfinance Institutions ( MFIs ): A Cost-Efficiency Analysis of BRAC, ASA, and PROSHIKA from Ba, (April).

Rashid, M. H. U., Uddin, M. J., \& Zobair, S. A. M. Islamic Microfinance and Sustainable Development Goals in Bangladesh.

Swain, R. B., \& Wallentin, F. Y. (2007). Does microfinance empower women? Evidence from selfhelp groups in India.

Wagner, C., \& Winkler, A. (2013). The Vulnerability of Microfinance to Financial Turmoil--Evidence from the Global Financial Crisis. World Development, 51, 71-90. https://doi.org/10.1016/j.worlddev.2013.05.008

Yunus, M. (2007). Credit for the Poor. Harvard International Review, 29(3), 20-24. Retrieved from http://content.epnet.com/ContentServer.asp?T =P\&P=AN\&K=28036378\&EbscoContent $=$ dGJy MNLe80SeqLY4y9f3OLCmrlGep7BSrqe4SrOWxWXS\&ContentCustomer=dGJyMOHX8nnq6 +yR3 7HreefkuX3m5fGM\&D=bsh 